\title{
Phraseological Transformations in Classical Works of English and Russian Literature
}

\section{Transformaciones fraseológicas en obras clásicas de la literatura inglesa y rusa}

\author{
Rimma Nailevna Salieva \\ Kazan Federal University, Russia \\ ORCID: 0000-0003-0515-7245 \\ Regina Maratovna Plankina \\ Kazan Federal University, Russia \\ ORCID: 0000-0001-7238-681X \\ Liliia Saimovna Sirazova \\ Kazan Federal University, Russia \\ ORCID: 0000-0002-6175-1508 \\ Rimma Abelkhaerovna Safina \\ Kazan Federal University, Russia \\ ORCID: 0000-0002-5787-1427
}

Received 09-08-20 Revised 10-10-20

* Correspondence

Email: sargus5@yandex.ru
Accepted 20-12-21 On line 03-01-21

\section{Citation:}

\footnotetext{
Rimma Nailevna Salieva, Regina Maratovna Plankina, Liliia Saimovna Sirazova, Rimma Abelkhaerovna Safina. (2021). Phraseological Transformations in Classical Works of English and Russian Literature. Propósitos y Representaciones, 9(SPE2), e1080. http://dx.doi.org/10.20511/pyr2021.v9nSPE2.1080
} 


\begin{abstract}
The article aims to reveal and analyze phraseological paradigm of transformed PUs in the context within two remote cognates. The following problems arise: 1) detection and analysis of semantics and semantic structure of transformed phraseological units; 2) allocation of general features of using such PUs in the context; 3) investigation of functioning of such PUs in classical works of English and Russian literature. Semantic, grammatical, componential and contextual aspects of using such phraseological units are analyzed in the present research. The paper presents the analysis and comparison of such linguistic systems as semantic macro and micro structures of PUs in English and Russian languages. The meaning of a PU presents a combination of two major macro components: 1) significative and denotative meaning and 2) connotative meaning. The semantic analysis of PUs gives us a fundamental understanding of existing of such micro components of meaning as estimation, emotionality, expressiveness and functioning in the context within the whole structure of meaning.
\end{abstract}

Keywords: phraseological unit; phraseological transformation; connotation; contextual use; stylistic effect.

\title{
Resumen
}

El artículo tiene como objetivo revelar y analizar el paradigma fraseológico de las UPP transformadas en el contexto de dos cognados remotos. Surgen los siguientes problemas: 1) detección y análisis de semántica y estructura semántica de unidades fraseológicas transformadas; 2) asignación de características generales del uso de tales PU en el contexto; 3) investigación del funcionamiento de tales UPP en obras clásicas de literatura inglesa y rusa. Los aspectos semánticos, gramaticales, componentes y contextuales del uso de tales unidades fraseológicas se analizan en la presente investigación.

El artículo presenta el análisis y la comparación de sistemas lingüísticos tales como macro y micro estructuras semánticas de UPP en los idiomas inglés y ruso. El significado de un PU presenta una combinación de dos macrocomponentes principales: 1) significado significativo y denotativo y 2) significado connotativo. El análisis semántico de las UPP nos da una comprensión fundamental de la existencia de microcomponentes del significado como la estimación, la emocionalidad, la expresividad y el funcionamiento en el contexto dentro de toda la estructura del significado.

Palabras clave: unidad fraseológica; transformación fraseológica; connotación; uso contextual; efecto estilístico.

\section{Introduction}

In Russia and in many foreign countries, multifaceted studies of phraseology have been flourishing in the course of the last decades. Despite the considerable amount of theoretical material on phraseology of Russian scientists (Telia, 1996; Федуленкова, 2018; Фёдоров, 2002), scholars of Kazan linguistic school (Ayupova et al., 2020; Байрамова, 2019; Kajumova et al., 2020; Kayumova et al., 2019; Plankina et al., 2019; Yakovleva et al., 2008; Yarullina et al., 2019; Zamaletdinov \& Faizullina, 2015; Aleeva \& Safiullina, 2016) and of foreign scholars (Cowie, 1998; Piirainen, 2008; Mieder, 2010), it is essential to reveal and analyze phraseological paradigm of transformed PUs in the context within two remote cognates. According to Ayupova, "phraseological studies became even more multiaspectual in the XXI century" (Ayupova et al., 2020). Revealing transformed PUs in the context is a case of great practical interest. The important point of our work is the investigation of peculiarities of phraseological transformations in the process of recognizing and understanding them. The present study aimed to find out the criteria for phraseological transformation; to investigate the nature and to examine each case of phraseological transformation; to describe significative and denotative, also connotative meaning of transformed units and to highlight cases of contextual transformation of PUs. 


\section{Methods}

It was necessary to use several advanced methods such as:

and Russian literature)

continuous sampling method (samples were taken from classical works of English method of phraseological identification;

method of phraseological description;

method of definitional analysis;

method of componential analysis;

method of semantic structural analysis;

- method of comparative analysis (phraseological phenomena is investigated and compared in two remote cognates).

Componential analysis, semantic analysis and analysis of transformed PU's semantic structure proved that these linguistic tools informed, inspired and attracted readers' or listeners' attention in both languages. These linguistic tools affected the audience of both cultures. The article presented the analysis and description of these linguistic tools used by authors of both cultures, as phraseological transformations of PUs were found in classic works of English and Russian literature.

\section{Results and Discussion}

The results of the study of transformed PUs in the context are presented. We are convinced that such PUs are active and productive in both languages. The results of the investigation are demonstrated and proved by the properties of materials.

As the basis of the analysis of language material, the following techniques of the authorial occasional transformations of PUs in English and Russian literature were taken: 1) Reduction of one or some more components; 2) adding one or some more components to the beginning of a PU; 3) adding one or some more components to the end of a PU.

I. Reduction of the number of components of a PU, namely, ellipsis; omission; truncation; the complicated deformation. The property of the constant composition of the PUs is used in this technique. It is enough to remind only some key components so that the whole PU is restored in the memory of the reader or listener. We will illustrate this fact by the following examples. In Russian:

В царстве небесном

Овцы все цель!

Спи, моя белая!

Больно не сделаю! (Цветаева, 2020).

A reader easily recognizes a phraseological unit и волки сыты, и овцы целы having the meaning 'everybody is satisfied with the events' in the author's poem, despite the fact that the poetess, transforming the PU gives only a part of it. The component $u$ showing repetition, the noun волки having the meaning 'wild, flesh-eating animal of the dog family' in its plural form, the component cblmbl having the meaning 'satisfied with eating, with food' are omitted; only the noun овиы having the meaning 'grass-eating animal kept for its flesh as food' is used in its plural form and the verb uель with the meaning 'was not taken into the mouth and swallowed by wolf' is used in its plural form too. The recipient easily catches the meaning of the PU in the context.

Another example in Russian:

Уже богов не те уже щедроты

На берегах не той уже реки.

В широкие закатные ворота.

Венерины летите голубки (Цветаева, 2020). 
Reduction of the component жизни having the meaning 'state of existence as a human being' doesn't deprive the recipient of the opportunity to recognize the PU река жизии having the meaning 'everything flows, everything changes' in the author's poem.

One more instance in Russian: “Силин: С моим удовольствием, и могу вас уверить, что вся дрянь, какая есть у меня на душе, будет сейчас на языке” (Прутков, 2020). In the context we find a complicated deformation of a phraseological unit что у трезвого на уме, то у пьяного на языке having the meaning 'a drunken man's words are a sober man's thought'. This example combines the reduction of the component sober having the meaning 'self-controlled; serious in thought; calm' and the component drunk having the meaning 'become affected by drinking alcoholic liquor'; then we observe the replacement of the component $y_{M}$ meaning 'brain' with the component $\partial y m a$ meaning 'emotional and intellectual energy' while the structure of PU is maintained. The meaning of the PU is easily recognizable in the context.

Here is an example in English: "Lord Ruthven soon formed this object into the hero of a romance, and determined to observe the offspring of his fancy, rather than the person before him" (Polidori, 2020). We observe the reduction of the components be, not used to make a negative and a personal pronoun $m y$ having the meaning 'belonging to me' in PU be not the hero of my romance having the meaning 'being not the hero of my novel'. Using such kind of stylistic device, phraseological unit acquires occasional antonymic use, loosing the original connotation of irony and gaining a new meaning in the context - Lord Ruthven, nevertheless made that lady the heroine of his romance.

II. Adding a component or components to the beginning of a phraseological unit is shown in the following illustrations.

In Russian: “Держись, сейчас еще больнее будет”, да с тем как дернет мою руку, аж⿻ красные искры у меня из глаз посыпались (Шолохов, 2020). Such components as aж having the meaning 'even as long as' and красные having the meaning 'of the color of rubies' were added to the beginning of PU искры из глаз посыпались having the meaning 'being very painful'. Moreover, such components as $y$ and меня meaning 'I have' were attached in order to image suffering body and to affect the reader emotionally.

In English: Mrs. Forrester rose to her feet. "Now I see what a gulf separates us", she said (Maugham, 2020). The component what having the meaning of exclamation was added to the beginning of PU a gulf separates us having the meaning 'a deep hollow; chasm; abyss between two sides' in order to increase the expressiveness and emotionality of the conversation in the described situation. Such occasional usage of PU helps the reader to capture characters' inner worries and to understand their relationship.

Another example in English: "... The maid was gone and the girl almost burst into tears" (Mansfield, 2020). The component almost having the meaning 'very nearly' was added to the beginning of PU burst into tears having the meaning 'suddenly begin to cry' in order to enhance the reader's impression and feeling of empathy with the heroine of the story.

As a further example we may examine the following context: "From increasing weakness I constantly was falling asleep, and constantly awaking" (Quincey, 2020). In this example, the component constantly having the meaning 'continuously, going on all the time' was added to the PU fall asleep having the meaning 'be in the condition of sleep'. We also find that the author uses an extended metaphor (we will discuss this stylistic device later). The image is expanded by repeating the component constantly and replacement the component asleep meaning 'sleeping' with the component waking meaning 'stop sleeping'. In this context we observe a play on these words. As a result, the reader, getting used to the situation, feels how awfully tired the hero is and how he is discontinuously waking up and falling asleep again. 
III. The following examples demonstrate the expansion of the phraseological unit by adding a component or components to the end of a phraseological unit.

In Russian: “Жонка у вас тишь да гладь, а кусачая", сказал мне первый незабвенный любовник Марфиньки. ... Это одно их тех воспоминаний, которые надо сразу гнать от себя" (Набоков, 2020). As we can see from this example, the conjunction $a$ meaning 'on the other hand' and the component кусачая meaning 'hard-bitten; toothy' were added to the end of the phraseological unit тишь да гладь having the meaning 'shy, modest, inconspicuous person' about Marfa to enhance the expressiveness of the conversation between Marfinka's husband and her former lover, to attach an ironic tone that the lover wants to give to the conversation. Another example of this method of phraseological transformation in Russian: “- Эй, ты, там, Кобыленко! Гляди в обе моргалки, а то попадешь носом в грязь! " (Мирнев, 2020). The component моргалки - a rude word, a jargon having the meaning 'eyes' was added to the end of PU гляди в об $\boldsymbol{a}$ having the meaning 'don't yawn, don't miss an opportunity' to attach an atmosphere of immediacy to the situation and to give some kind of rudeness and arrogance to the stylistically reduced conversation between two young men sorting out their relationship. In addition, we observe an extension of the metaphorical image thanks to the usage of another PU within the same sentence. It is stylistically colloquial and expressive phraseological unit не ударить лицом в грязь having the meaning 'do not make a mistake, do not be ashamed, perform something in the best way, show yourself at your best'.

The author of the example above transforms PU in the following interesting way: the component не used to make a negative' is not clipped; the component ydapumb having the meaning 'hit smb' is replaced by the component nonademb meaning 'have or turn the face in a certain direction'; the component лицом meaning 'the front part of the head' is replaced by the component носом meaning 'part of the face above the mouth'; only the component грязь having the meaning 'disgrace' remains unchanged; as a result, the antonymous meaning of PU is being acquired - 'to drop a clanger, to shame by doing smth not the best way, to show their worst side'. But the phraseological unit не ударить лицом в грязь is easily recognizable in the context. Thus, this phraseological unit gives a vivid expression to the entire utterance of speech. The componential and semantic criteria of forming expressiveness are combined together and have enhancing properties of imagery within the semantic structure of this PU. They have played their role and served as the basis for phraseological semantics and for representing bright characters in the context.

We give here another example in English language: "That's the one place I will not go. Heat is the one thing I can't stand", I said laughing. Mrs. Jones was nonplussed for a moment" (Leacock, 2020). In this example such components as for used as the preposition of time, the article $a$ and the noun moment meaning 'very brief period of time' are added to the end of a phraseological unit to be nonplussed having the meaning 'surprise or puzzle so much that smb does not know what to do or say'; the antonymous meaning of the phraseological unit is also used to emphasize the fact that Mrs. Jones was not really confused by this response. In fact, she knew and was sure of what to say and to do next. The author needed to emphasize great confidence and absence of hesitation.

It is interesting and important to note that our research enabled us to obtain concrete results. Researchers identify from three to eleven different devices of PU's transformation. We investigated 100 of PUs in English classic works and 100 of PUs in Russian classic works. We have revealed three of these methods. The results indicate that phraseological transformations are attractive linguistic tools for authors of both different cultures, but to a different extent. These results are of considerable interest.

\section{Summary}

The current research studied the concept of traditional understanding of a context. In most cases, a phraseological unit within a sentence or some more sentences was investigated. Much of the material presented in our work proves that the meaning of transformed phraseological units is 
really very much dependent on the contexts in which they are used. The analysis has indicated that there are common and different features within two remote cognates when we find phraseological transformations in classical works of native and foreign languages. Results provided further, better and clearer ways of collecting and understanding new information on classical works of both English and Russian literature.

\section{Conclusions}

The general conclusion to be drawn from these examples and this discussion is that the language of classic works of both English and Russian literature is a complex unity comprising a vast number of elements. The use of original phraseological transformations is one of these elements. Author's individual transformations of PUs are inseparable part of both cultures; they prove that transformed phraseological units often occur quickly to convey certain information; to express reader's attitude and assessment of reading as well as to enhance PUs' evaluative, emotional and expressive components of denotative meaning, etc. It is claimed that transformed phraseological unit plays vital role in the process of communication to be very emotive and expressive. The study proves the importance of revealing common and different features of occasional transformations in the context within two remote cognates.

\section{Acknowledgements}

The work is performed according to the Russian Government Program of Competitive Growth of Kazan Federal University.

\section{REFERENCES}

Aleeva, G.K., \& Safiullina, G.R. (2016). Using dictionaries in teaching English as a foreign language. International Journal of Environmental and Science Education, 11(9), 27272734.

Ayupova, R., Arsenteva, E., Lutfullina, G., \& Nikulina, E. (2020). Identifying The Key Components Of Phraseological Units. Humanities and Social Sciences Reviews, 8(1), 233239.

Cowie, A. P. (1998). Phraseology: Theory, analysis, and applications. OUP Oxford.

Kajumova, D.F., Sadykova, A.G., Davletbaeva, D.N., \& Aleeva, G.H. (2020). Using of phraseological units of the concept "the fate of man" in the lessons of Foreign languages. International Journal of Psychosocial Rehabilitation, 24(3), 1863-1870.

Kayumova, A., Konopleva, N., \& Safina, R. (2019). Linguo-cultural peculiarities of phraseological units with the component "fire" in English, Russian, Spanish, Tatar and German". XLinguae, 12(3), 55-65.

Kržišnik, E., \& Eismann, W. (2007). Phraseology in linguistics and other branches of science. Ljubljana: Univerza v Ljubljani.

Leacock, S. (2020). The Hallucination of Mr. Butt. URL: https://archive.org/stream/leacockroundabo00leac/leacockroundabo00leac djvu.txt (accessed: 30.09.2020).

Mansfield, K. (2020). A Cup of Tea. URL:http://studyguide.org/mansfield_cup_of_tea.htm (accessed: 12.09.2020).

Maugham, W. (2020). The Creative Impulse", URL:yablokova.net content/uploads/2018/09/maugham... (accessed: 08.09.2020).

Mieder, W. (2010). International Bibliography of Paremiology and Phraseology. de Gruyter, vol. 1: A-M., 2: N-Z.

Piirainen, E. (2008). Figurative Phraseology and Culture", Phraseology: An Interdisciplinary Perspective, 423-425.

Plankina, R.P., Pestova, M.S., Tarasova, F.H., \& Yakhina, A.M. (2019). Evaluative Component in the Meaning of Verbal Phraseological Units of English, Russian and Tatar Languages. Journal of Research in Applied Linguistics, 10(2), 762-769.

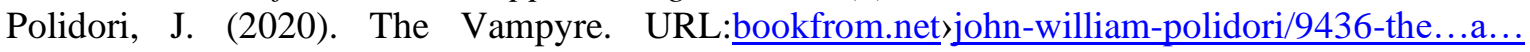
(accessed: 30.08.2020). 
Quincey, T.H. (2020). Confessions of an English Opium Eater. URL: https://archive.org/details/confessions_opium-eater_mg_librivox (accessed: 18.09.2020).

Telia, V.N. (1996). Russian Phraseology. Semantic, Pragmatic and inguoculturological Aspect. Languages of Russian culture,

Yakovleva, S.L., Solnyshkina, M.I., \& Soldatkina, T.A. (2008). The concept of MIND in ENGLISH, RUSSIAN and MARI phraseology", Proceedings of ADVED 2018- 4th International Conference on Advances in Education and Social Sciences, 297-301.

Yarullina, O., Tarasova, F., Salieva, R., \& Luzenina, I. (2019). Semantic aspect of phraseological units with components denoting weather in the process of cross-cultural communication in English, Russian and Spanish languages. Journal of Interdisciplinary Research, 8(09/02VIII.), 13-15.

Zamaletdinov, R., \& Faizullina, G. (2015). Metaphorization of mythonyms as the way of a person secondary nomnation in the siberian dialects of tatar language. Journal of Language and Literature, 6(2), 59-63.

Байрамова, Л.К. (2019). Лингвокультурологические коды образных компонентов фразеологизмов о Родине. Казанская наука, 8, 35- 40.

Мирнев, В. (2020). Знакомые лица. URL:https://search.rsl.ru/ru/record/01001220051 (accessed: 22.09.2020).

Набоков, В. (2020). Приглашение на казнь. URL: https://polka.academy/articles/568 (accessed: 18.09.2020).

Прутков, К. (2020). Любовь и Силин. Сочинения Козьмы Пруткова. URL: https://ruslit.traumlibrary.net/book/prutkov-sochinenia/prutkov-sochinenia.html, (accessed: 22.08.2020).

Фёдоров, А. (2002). Основы общей теории перевода: Для институтов и факультетов иностр. языков.

Федуленкова, Т. (2018). Современная английская фразеология со структурным компонентом. Язык и культура, 43, p. 115.

Цветаева, М. (2020). Хвала Афродите. URL:https://cvetaeva.su/hvala-afrodite/ (accessed: 12.08.2020).

Цветаева, М. (2020). “Сын”, URL:https://www.culture.ru/poems/34950/syn (accessed: 04.08.2020).

Шолохов, M. (2020). “Рассказы”. URL:https://www.bookol.ru/prozamain/sovetskaya_klassicheskaya_proza/144019.htm (accessed: 30.08.2020). 